\title{
Study of Liquid Waste Quality and Potential Pollution Load of Motor Vehicle Wash Business in Bekasi City (Indonesia)
}

\author{
Elanda Fikri ${ }^{* *}$, Arifah Nur Shabrina Putri ${ }^{2}$, Teguh Budi Prijanto², Osman Syarief ${ }^{3}$ \\ 1 Department of Environmental Health, Bandung Health Polytechnic, Cimahi Utara, Doctorate Program of \\ Environmental Studies, Diponegoro University, Semarang, 50241, Indonesia \\ 2 Department of Environmental Health, Bandung Health Polytechnic, Cimahi Utara, 40514, Indonesia \\ 3 Department of Health Nutrition, Bandung Health Polytechnic, Cimahi Utara, 40514, Indonesia \\ * Corresponding author's e-mail: elandafikri@yahoo.com
}

\begin{abstract}
The increasing number of motor vehicles in Bekasi city each year has led to the development of the motor vehicle wash business that can cause water pollution due to the resulting liquid waste. The use of various chemicals in these activities is one factor that affects the quality of liquid waste. This study aims to identify the quality of the liquid waste from motor vehicles wash in Bekasi city. The sample in this study was the liquid waste from the semi-automatic motor vehicles wash business in the North Bekasi region. The result of the research conducted in 3 locations showed that the processing of liquid waste produced was not carried out before being discharged into the environment. The results of test parameter presented in location 1, location 2, and location 3, respectively, were $\mathrm{pH}$ around 6.0, 5.0, and 4.8. TSS was $279.7 \mathrm{mg} / 1,259.4 \mathrm{mg} / 1,333.6 \mathrm{mg} / 1, \mathrm{COD}$ was $657.1 \mathrm{mg} / 1,182.1,460.0 \mathrm{mg} / \mathrm{l}$, oil and fat were $79.1 \mathrm{mg} / 1,46.2 \mathrm{mg} / 1,86.7 \mathrm{mg} / \mathrm{l}$, phenol was $2.7 \mathrm{mg} / \mathrm{l}, 1.5 \mathrm{mg} / \mathrm{l}, 3.2 \mathrm{mg} / \mathrm{l}$, and the highest potential pollution load was in COD parameter and TSS. Therefore, it is recommended that a motor vehicle wash business begins to pay attention to the impact of liquid waste by processing it before discharging into the environment and the Bekasi City government should begin to control water pollution, especially in those businesses.
\end{abstract}

Keywords: quality of liquid waste, pollution load, motor vehicle wash business

\section{INTRODUCTION}

Water pollution involves the entry or inclusion of organisms, substances, energy, and / or other components into the water, as a result of which the water quality drops to a certain level that causes the water to no longer function in accordance with its designation (Ministry of Environment Regulation Number 1 of 2010 concerning Management of Water Pollution Control). Pollution can occur due to various factors, one of which comes from human activities, namely business activities. This has an impact on the number of businesses that are currently developing, one of which is the washing of motor vehicles.

Nowadays, there are many vehicle wash business in various regions in Indonesia, supported by its practicality. However, the vehicle wash business can worsen the environmental quality and also disrupt the public health. This is due to the characteristics of the vehicle wash waste containing such pollutants as BOD, COD, TSS, detergent (surfactant), oil, and fat. The vehicle washing wastewater that is not subjected to processing first but is directly discharged into a body of water can pollute the river water.

Especially the pollution due to the presence of high oil and fat in the body of water will cause a decrease in the quality of water body. This is caused by the nature of oil that is difficult to decompose so that it can cause a decrease in the self-purification of the water body (Herganintya, et al., 2014, El-Gawad, 2014). The decline in the ability of self-purification is characterized by a low oxygen content in the water (Dissolved Oxygen) which can interfere with the biota life in the river and cause pollution to the surface water and soil; additionally, it may constitute a medium for 
the proliferation of pathogenic microorganisms and vector carrying disease. In addition, the composition of oil and fat also contains many harmful ingredients (such as phenols and polyaromatic hydrocarbons) that are carcinogenic to humans (Lau W, et al., 2013; Kwach, et al., 2009 in Ibrahim and Hashim, 2018).

The vehicle wash businesses in Indonesia still do not process their laundry waste before discharging it into a water body. On the basis of the research conducted by Herganintya, et al. (2014), the oil and fat content in car wash liquid waste was $36 \mathrm{mg} / \mathrm{L}$, and COD $700 \mathrm{mg} / \mathrm{L}$, the study by Setiawan and Situmorang (2017) conducted in Karawang Regency indicated the values from $86-159 \mathrm{mg} / \mathrm{L}$ and COD $87.54 \mathrm{mg} / \mathrm{L}$, and the research conducted by Pranoto (2017) in Yogyakarta showed the value of oil and fat was $51 \mathrm{mg} / \mathrm{L}$ and COD was $425 \mathrm{mg} / \mathrm{L}$. In turn, Evy et al. (2013) carried out research in Malang and reported that the value of oil and fat was 29.33 $\mathrm{mg} / \mathrm{L}$, COD was $549 \mathrm{mg} / \mathrm{L}$, and TSS $272 \mathrm{mg} / \mathrm{L}$ which had exceeded the liquid waste quality standard set in Ministry of Environment Regulation Number 5 of 2014 concerning Wastewater Quality Standard which refers to the Wastewater Quality Standards of Businesses and/or Activities that do not have a Defined Wastewater Quality Standard.

The river pollution, especially in the Bekasi City, has become a crucial problem. The rivers in Bekasi are now highly polluted, which is characterized by being covered with white foam, pungent odor, and also blackened dirt; therefore, the source of pollutants in Bekasi is assumed to be domestic waste $(60 \%)$ and industrial waste (40\%) (Putri, 2018).

The Bekasi City is a part of a megapolitan area, namely Mega City Jabodetabek, which is the second largest urban area in Asia after Tokyo Metropolitan City which is $0.35 \%$ of the total area in Indonesia and inhabited by $11.3 \%$ of Indonesia's population (Pravitasari et al., 2015). The data from Central Statistics Agency in 2018 showed that the population growth rate was $1.47 \%$ with population density reaching 13,318 people $/ \mathrm{km}^{2}$. It was projected that the Bekasi City would experience a population explosion up to 3.6 million by the year 2022. The rapid population growth in the Bekasi City will result in changes in patterns and lifestyles, as well as increasingly high standard of living with increasing demand for goods and services. The need for motor vehicle wash business is no exception.
On the basis of the data of Central Statistics Agency (2016), the number of private two and four-wheeled vehicles in the Bekasi City reached $1,572,922$ vehicles, with $1,259,146$ motorcycles and 313,776 cars. Therefore, the vehicle wash business in Bekasi city can potentially pollute the environment.

This study aims to identify the existing condition of liquid waste treatment and the quality of liquid waste in terms of $\mathrm{pH}, \mathrm{COD}$, TSS, oil, fat, and phenol, also potential pollution load from COD, TSS, oil, fat, and phenol parameters of the wash business in the Bekasi City.

\section{MATERIALS AND METHODS}

The type of conducted research was descriptive. The research was carried out in 3 vehicle wash business locations in North Bekasi Subdistrict in May 2019. The population was divided into two types, which were the population of locations, namely all motorbike wash locations in the Bekasi City, and environmental population, namely all liquid waste of motor vehicle wash business in the Bekasi city.

The location sample in this study was a semiautomatic type vehicle wash business. The sampling technique used was purposive sampling. The environmental samples in this study comprised the liquid waste from the semi-automatic motor vehicle wash activities, with a total sample of 3 liters from each location. The sampling method used was composite sampling based on the solid time of wash business.

The data was processed using a computer, and was analyzed with the information obtained from observations and related theories and also analyzed by comparing the quality standard of Ministry of Environment Regulation Number 5 of 2014 concerning the Wastewater Quality Standards that refer to Wastewater Quality Standards Businesses and/or activities that do not yet have a defined liquid waste quality standard.

\section{RESULTS AND DISCUSSION}

\section{Existing condition for liquid waste management of motor vehicle wash}

The existing condition in 3 business locations for washing motor vehicles is that the liquid waste produced is not processed first but directly discharged into rivers and sewers around the wash 


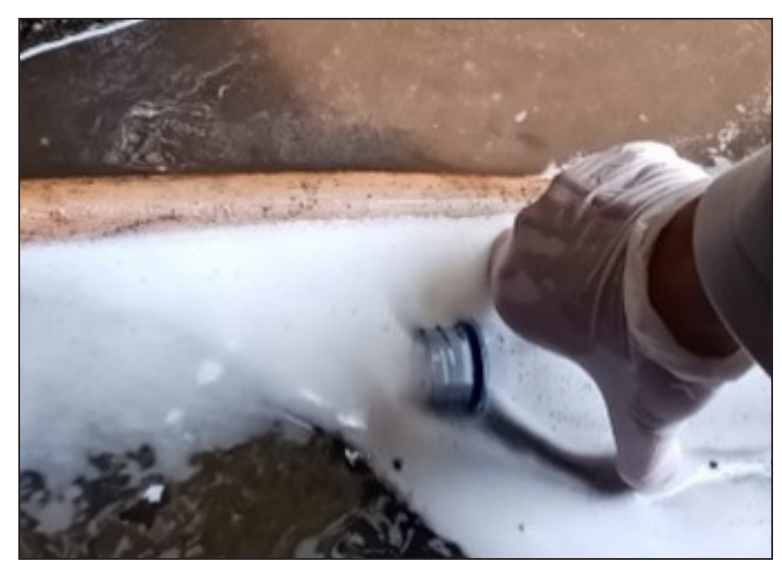

Fig. 1. Sampling of waste water to prevent aeration

business. The liquid waste produced from the three locations can be visually seen as it is colored, smelling, foaming, as well as there are films or layers of oil and fat that can potentially pollute the river water and groundwater indirectly.

On the basis of these conditions, the liquid waste treatment activities need to be carried out. The wastewater treatment activities aim to eliminate the pollutant parameters that exist in liquid waste to the extent permitted to be discharged into water body in accordance with the standard requirements. The liquid waste treatment processes can be divided into primary processing (primary treatment), secondary processing (secondary treatment), and tertiary processing or further processing (Said, 2017).

\section{Quality of motor vehicle wash liquid waste} pH Level

On the basis of Table 1, it can be seen that the $\mathrm{pH}$ level in the liquid waste of motor

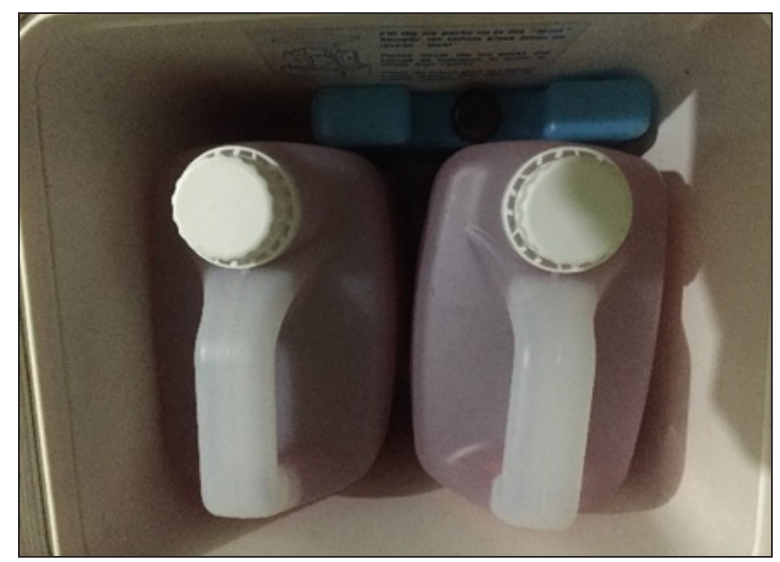

Fig. 2. Treatment of samples (stored in cool boxes with ice packs)

vehicles wash business in location 1 is 6.0 , location 2 is 5.0 , and location 3 is 4.8 , i.e. the liquid waste has acidic $\mathrm{pH}$. When compared with the Republic of Indonesia Ministry of Environment Regulation Number 5 of 2014 concerning the Wastewater Quality Standards where the value of the standard $\mathrm{pH}$ level is $6-9$, it can be said that location 1 has fulfilled the requirements while locations 2 and 3 do not meet the requirements.

This can be ascertained because of the use of shampoo, soap, or detergent in the washing process where builders increase the efficiency of surfactants by creating appropriate acidity conditions so that the washing process can take place properly by dispersing and suspending impurities (Minaqua, 2016).

The impact of an abnormal $\mathrm{pH}$ level will change the $\mathrm{pH}$ of the water, which will further disrupt the life of microorganisms in the water (Nadhiroh, 2014).

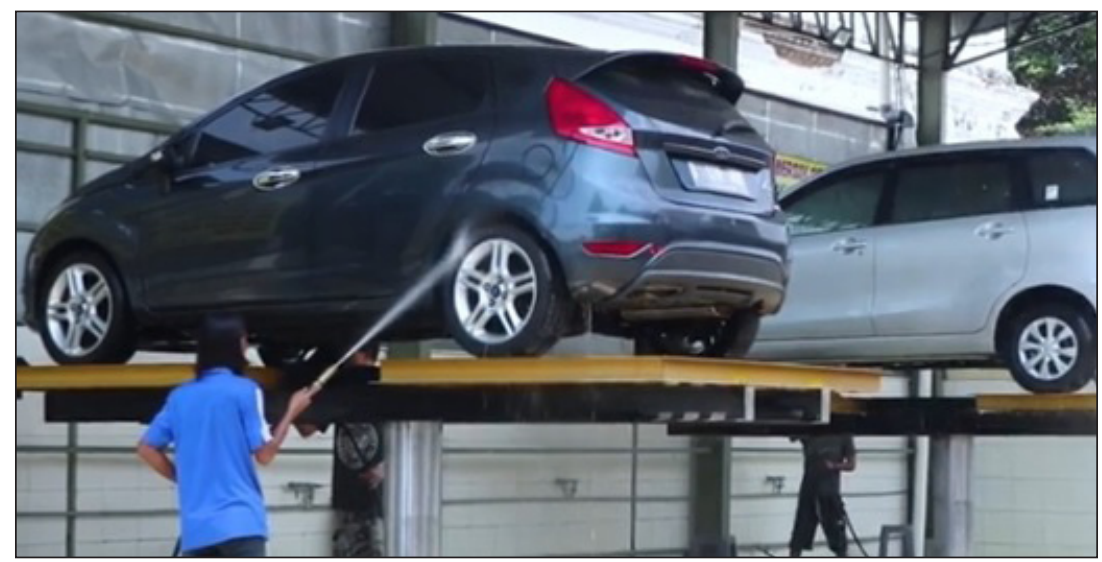

Fig. 3. Washing process using high pressure 


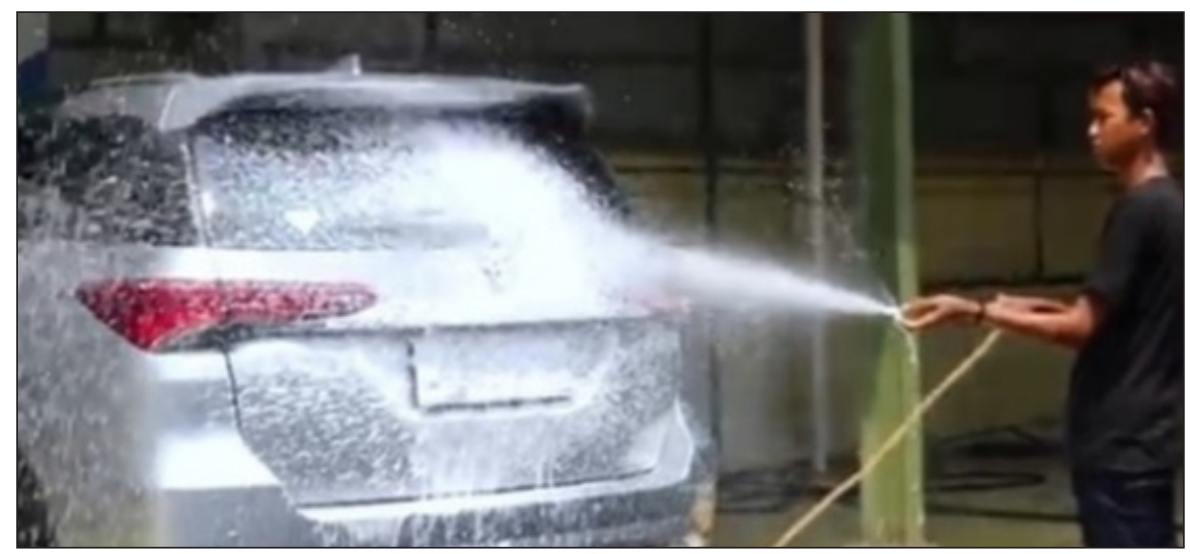

Fig. 4. The process of giving detergents

Table 1. $\mathrm{pH}$ level of motor vehicle liquid waste

\begin{tabular}{|c|c|c|c|c|}
\hline Location & pH level & Raw quality & Note & Analysis method \\
\hline Location 1 & 6.0 & $6-9$ & Qualified & \multirow{2}{*}{ SNI 6989.73:2009 } \\
\cline { 1 - 3 } Location 2 & 5.0 & $6-9$ & Unqualified & \\
\hline Location 3 & 4.8 & $6-9$ & Unqualified & \\
\hline
\end{tabular}

\section{Debit}

On the basis of Table 2, it can be seen that the highest liquid waste discharge produced by the motor vehicle wash business is at location 1 which is $28.5 \mathrm{ml} / \mathrm{sec}$ and the lowest liquid waste discharge that is produced is at location 3 .

\section{Total Suspended Solid (TSS)}

Table 3 indicates that the highest TSS value contained in the liquid waste from the motor vehicle wash business is at location 2 , which is $359.4 \mathrm{mg} / \mathrm{L}$. When compared with the wastewater quality standards according to RI Ministry of Environment Regulation Number 5

Table 2. Debit data of liquid waste from the motor vehicles wash business in Bekasi City in 2019

\begin{tabular}{|c|c|}
\hline Location & Debit $\left(\mathrm{m}^{3} /\right.$ second $)$ \\
\hline Location 1 & $28,5 \times 10^{-6}$ \\
\hline Location 2 & $28,0 \times 10^{-6}$ \\
\hline Location 3 & $27,6 \times 10^{-6}$ \\
\hline
\end{tabular}

of 2014 concerning Wastewater Quality Standards which is $200 \mathrm{mg} / \mathrm{L}$, it can be concluded that the TSS content in liquid waste in the motor vehicles wash business has exceeded the limit. The TSS content in the three locations can be affected because the impurities contained in the vehicle are carried along during washing.

According to Phungula (2016), there were several pollutants attached to motor vehicles which were classified into 3 types, the first one was traffic pollutants including dust, heavy metal particles, oil and fat, brake pads, the second one was environmental factors including dirt due to the road condition used by vehicles, the third one was vehicle wash chemicals such as detergent and vehicle shampoo.

It is also supported by high-pressure washing equipment that is able to completely clean the surface of the vehicle. In addition, the use of shampoo, soap, or detergent in washing also affects the presence of the TSS content. This is in line with the research conducted by Hashim and Ibrahim (2018) in Malaysia, where the motor

Table 3. TSS content data of liquid waste from motor vehicles wash business in Bekasi City in 2019

\begin{tabular}{|c|c|c|c|c|}
\hline Location & TSS $(\mathrm{mg} / \mathrm{L})$ & Raw quality $(\mathrm{mg} / \mathrm{L})$ & Note & Analysis method \\
\hline Location 1 & 279,7 & 200 & Unqualified & \multirow{2}{*}{ APHA Section 2540 D } \\
Location 2 & 359,4 & 200 & Unqualified & Ed 2017 \\
\hline Location 3 & 333,6 & 200 & Unqualified & \\
\hline
\end{tabular}


vehicles wash business using high pressure washing equipment produced liquid waste with a TSS content of $392 \mathrm{mg} / \mathrm{L}$.

The impact of the TSS content could affect the condition of waters because high concentration could interfere with life in the water which blocked sunlight which helped plants to carry out photosynthesis (Ningrum, 2019)

\section{Chemical Oxygen Demand (COD)}

On the basis of Table 4 above, it can be seen that the highest COD content in the liquid waste from motor vehicles wash business is at location 1 which is equal to $657.1 \mathrm{mg} / \mathrm{L}$. When compared with the value of the wastewater quality standards according to RI Ministry of Environment Regulation Number 5 of 2014 concerning Wastewater Quality Standards for COD parameters of $100 \mathrm{mg} / \mathrm{L}$, the third liquid waste of the vehicle wash business has exceeded the standards set or can be said to be ineligible.

The COD content is influenced by the chemicals found in shampoo, soap, or detergent used in the washing process. The ingredients contained in shampoo, soap, or detergent in all three wash businesses of detergent motor vehicles with an active ingredient, namely anionic surfactant.

In general, a detergent is composed of three components, namely surfactant (as a base material) of $20-30 \%$, builders (phosphate compounds) of $70-80 \%$, and additives (bleach and fragrance) which are relatively small, namely $2-8 \%$. The phosphate content or Sodium Tripolyphosphate (STTP) in shampoo, soap, or detergent can stimulate the growth of water weeds. The growth of water weeds will cause an increase in phosphate decomposition, and an inhibition of the exchange of oxygen in water so that dissolved oxygen level in water is low (Kirk and Othmer, 1982 in Yuliani, et al. 2015).
The difference in the COD content in the liquid waste produced by the three motor vehicles wash business activities is likely to occur due to the amount of shampoo, soap, or detergent used differently such as the dosage of use.

The impact of the COD content directly discharged into a body of water will reduce dissolved oxygen in water, can threaten the extinction of organisms in the water, and can also lead to the emergence of anaerobic conditions, namely foul odors and aesthetic problems (Ningrum, 2018). In addition, according to Wibowo (2013), the water quality also affects health, given the nature of water which is easily contaminated by various microorganisms and is very easy to dissolve various materials. The condition of the water nature makes it a medium for easily channeling or spreading disease.

\section{Oil and Fat}

Table 5 indicates that the highest oil and fat content in the motor vehicles wash business at location 3 is $86.7 \mathrm{mg} / \mathrm{L}$. When compared with the quality standard according to RI Ministry of Environment Regulation Number 5 of 2014 concerning Wastewater Quality Standards for oil and fat parameters, which is $10 \mathrm{mg} / \mathrm{L}$, the oil and fat content in the liquid waste from the motor vehicles wash business has exceeded the standard set, namely $5 \mathrm{mg} / \mathrm{l}$.

The presence of oil and fat content in liquid waste resulted from the use of detergent or soap in washing motor vehicles can clean the presence of oil and fat. According to Khanmohammadi et al. (2007) in Puspitasari, et al. (2013), the active ingredients of shampoo, soap, or detergent were surfactants which could increase the water wetting so that fatty impurities could be moistened and lifted.

The washing activities on vehicle engines may remove the oil attached to the equipment

Table 4. COD content data of liquid waste from motor vehicles wash business in Bekasi City in 2019

\begin{tabular}{|c|c|c|c|c|}
\hline Location & COD $(\mathrm{mg} / \mathrm{L})$ & Raw quality $(\mathrm{mg} / \mathrm{L})$ & Note & Analysis method \\
\hline Location 1 & 657,1 & 100 & Unqualified & \multirow{2}{*}{ SNI 6989.73-2009 } \\
\cline { 1 - 4 } Location 2 & 182,1 & 100 & Unqualified & \\
\hline Location 3 & 460,0 & 100 & Unqualified & \\
\hline
\end{tabular}

Table 5. Oil and Fat Content Data of Liquid Waste from the Motor Vehicles Wash Business in Bekasi City in 2019

\begin{tabular}{|c|c|c|c|c|}
\hline Location & Oil and fat $(\mathrm{mg} / \mathrm{L})$ & Raw quality $(\mathrm{mg} / \mathrm{L})$ & Note & Analysis method \\
\hline Location 1 & 79,1 & 10 & Unqualified & \multirow{2}{*}{ APHA Section 5520 oil \& fat F } \\
Location 2 & 46,2 & 10 & Unqualified & Unqualified 2017 \\
\hline Location 3 & 86,7 & 10 & Un \\
\hline
\end{tabular}


when being cleaned or a leak of gasoline. This is in line with the research conducted by Pranoto in 2017 where the engine cleaning activities on vehicles caused the presence of oil and grease in the liquid waste from the motor vehicle wash.

\section{Phenol}

Table 6 shows that the highest phenol content is in liquid waste. The third location of vehicle wash business is $3.2 \mathrm{mg} / \mathrm{L}$. If compared with related regulations, namely with Republic of Indonesia Ministry of Environment Regulation Number 5 of 2014 concerning Wastewater Quality Standards for the phenol parameter, which is 0.5 $\mathrm{mg} / \mathrm{L}$, it can be seen that the phenol content of the three motor vehicle wash businesses has exceeded the existing quality standard or is ineligible.

The presence of the phenol content in the liquid waste from motor vehicle wash business is influenced by oil and fat content. According to Kwach et al. (2009), the content of oil and fat is complex and can also contain many hazardous substances (such as phenols and polyaromatic hydrocarbons). It can be said that the phenol content is related to the presence of oil and fat and it can be seen also that location 3 is the location where the liquid waste contains the highest phenol which is $3.2 \mathrm{mg} / \mathrm{L}$. Location 3 is also the location with the highest oil and fat content among other locations.

The impact of the phenol content on a water body will cause unpleasant taste and smell, and at certain concentration values, it can cause the death of aquatic organisms because it is classified as dangerous, corrosive, and toxic. (Ariyani, 2011). In addition, the effect of phenol on humans can cause irritation to the eyes, nose, and throat. Phenol is toxic to the respiratory system and can cause damage to the nervous system tissue if it is consumed or continuously inhaled (Faisal and Saksono, 2013)

\section{Potential Pollution Load}

On the basis of the Regulation of Ministry of Environment Number 1 of 2010 concerning Management of Water Pollution Control, it is stated that the water pollution load is the amount of a pollutant contained in wastewater.

The wastewater is discharged directly into Bekasi river and for locations 2 and 3 indirectly also flowed into Bekasi riverł therefore, it can potentially reduce the River Pollution Load Capacity of the Bekasi City which will reduce the water quality disturbing the function of the ecosystem. Pollution of rivers also has the potential to pollute groundwater. Groundwater can be either deep well water or shallow well water (Ningrum, 2018).

Table 7 shows that the highest potential pollution load in liquid waste is at the first location of the vehicle wash business; it corresponds to the chemical oxygen demand (COD) parameter, which is $1.6 \mathrm{~kg} /$ day. At location 2, the highest potential pollution load in liquid waste is total suspended solid (TSS) parameter, which is 0.87 $\mathrm{kg} /$ day. At location 3, the highest potential pollution load in the liquid waste from the motor vehicle wash business is chemical oxygen demand (COD) parameter which is equal to $1.09 \mathrm{~kg} /$ day.

\section{CONCLUSION}

The existing condition of the liquid waste treatment of the motor vehicle wash business in 3

Table 6. Phenol content data of liquid waste from motor vehicle wash business in Bekasi City in 2019

\begin{tabular}{|c|c|c|c|c|}
\hline Location & Phenol (mg/L) & Raw quality (mg/L) & Note & Analysis method \\
\hline Location 1 & 2,7 & 0,5 & Unqualified & \multirow{3}{*}{$\begin{array}{c}\mathrm{IKM} / 7.2 .90 / \mathrm{MB} \\
\text { (Spectrophotometry) }\end{array}$} \\
\hline Location 2 & 1,5 & 0,5 & Unqualified & \\
\hline Location 3 & 1,2 & 0,5 & Unqualified & \\
\hline
\end{tabular}

Table 7. Potential pollution load of liquid waste from motor vehicle wash business at Location 1, Location 2, and Location 3

\begin{tabular}{|c|c|c|c|}
\hline \multirow{2}{*}{ Parameter } & \multicolumn{3}{|c|}{ Potential Pollution Load (kg/day) } \\
\cline { 2 - 4 } & Location 1 & Location 2 & Location 3 \\
\hline TSS & $6,8 \times 10^{-1}$ & $8,7 \times 10^{-1}$ & 1,09 \\
\hline COD & 1,6 & $4,4 \times 10^{-1}$ & $2 \times 10^{-1}$ \\
\hline Oil and Fat & $1,9 \times 10^{-1}$ & $1,1 \times 10^{-1}$ & $6 \times 10^{-4}$ \\
\hline Phenol & $6 \times 10^{-4}$ & $3 \times 10^{-4}$ & \\
\hline
\end{tabular}


locations as the research sites found that no processing of the liquid waste was conducted before being disposed of into the environment, i.e. no liquid waste treatment was carried out.

The highest potential liquid waste pollution load for the motor vehicle wash business per parameter at location 1 was Chemical Oxygen Demand (COD) parameter of $0.68 \mathrm{~kg} / \mathrm{day}$, in location 2 was Total Suspended Solids (TSS) parameter, namely at $0.87 \mathrm{~kg} / \mathrm{day}$, and at location 3 was Chemical Oxygen Demand (COD) parameter which was equal to $1.09 \mathrm{~kg} /$ day.

\section{Acknowledgements}

This study was financially supported by Unit Penelitian dan Pengabdian Masyarakat (UPPM) Poltekkes Kemenkes RI Bandung, Ministry of Health, Indonesia scheme.

\section{REFERENCES}

1. Ariyani S.B. 2011. Decreasing phenol levels in cases of herbal medicine waste with the anaerobic active mud method. Biopropal Industri, 2(1), 14-20.

2. Central Bureau of Statistics Indonesia. 2017. Development of number of motor vehicles by type, 1949-2016. Accessed from: https://www.bps.go.id/ linkTableDinamis/view/id/1133.

3. Central Bureau of Statistics Indonesia. 2018. Number of public and non-general vehicles for BPKB according to branch services in West Java. Accessed from: https://jabar.bps.go.id/statictable/2018/03/19/416/jumlah-kendaraan-bermotorumum-dan-bukan-umum-untuk-bpkb-menurutcabang-pelayanan-di-jawa-barat-2016.html.

4. Evy A., Agusfian. 2013. Decreasing COD, TSS, and fat oil in car wash liquid waste with trickling filter processing unit. case study of car wash liquid waste "The Auto Bridal", Malang. Ph.D. Thesis, Institut Teknologi Nasional, Malang.

5. Faisal Y.E., Nelson S. 2013. Phenol degradation in liquid waste by Contact Glow Discharge Electrolysis (CGDE) method using KOH electrolytes. Ph.D. Thesis, Universitas Indonesia, Depok.

6. Hargianintya A., Heru S., Wiharyanto O. 2014. Treatment of car washing liquid waste using 10 and $25 \mathrm{kda}$ supported ultrafiltration technology. Jurnal Teknik Lingkungan, 3(4), 1-8.

7. Ibrahim M.S.S., Hashim N.H. 2018. Removal of oil and grease and anionic Surfactants in Synthetuc Car Wash Wastewater using Kapok Fiber: A BatchScale Study. Malaysian Journal of Analytical Science, 22(4), 735-741.
8. Indonesian Minister of Environment Regulation Number 5 of 2014 About waste water quality standards.

9. Indonesian Minister of Environment Regulation Number 1 of 2010 About Management of Water Pollution Control.

10. Kwach B.O., Lalah J.O. 2009. High concentrations of polycyclic aromatic hydrocarbons found in water and sediments of car wash and kisat areas of winam gulf, lake victoria-Kenya. Bull Environ Contam Toxicol, 83(5), 727-733.

11. Minaqua. 2016. Good Prattices Guide for Car Wash Installations. Accessed from: http:/www.minaqua. org/wp14/wp-content/uploads/2016/12/Good-practices-guide-for-car-wash-installations-ENG-bxa.pdf.

12. Nadhiroh Y. 2014. Analysis of Sungai Pakis Water Quality Due to Waste of New Fern Sugar Factory in Tayu District, Pati Regency. Ph.D. Thesis, Universitas Muhammadiyah, Surakarta.

13. Ningrum S.O. 2018. Analysis quality of water river and quality of well water in the surrounding of Rejo Agung Baru Sugar Factory Madiun. Jurnal Kesehatan Lingkungan, 10(1), 1-12.

14. Phungula S.P. 2016. An evaluation of the water quality and toxicity of wastewater at selected car wash facilities in Tshwane, Gauteng. Ph.D. Thesis, Environmental Science Univesity of South Africa.

15. Pranoto. 2017. Effectiveness of carbon biofilter Aero Reactor on Decreasing COD and Fat Oil concentration in the Auto Bridal washing liquid waste motor vehicles 10. Ph.D. Thesis, Universitas Islam Indonesia, Surakarta.

16. Pravitasari A.E., Saizen I., Narumasa T., Ernan R. 2015. Specific dependent driving forces of urban expansion in an emerging asian megacity: the case of greater Jakarta (Jabodetabek). Journal of Sustainable Development, 8(1), 108-119.

17. Puspitasari, Arnelli, Susesono A. 2013. Washing solution formulation of laundry waste substrate surfactant. Jurnal Kimia Sains dan Aplikasi, 16(1), 11-16.

18. Putri R.D. 2019. Household waste makes bekasi river add polluted. Accesed from: https://tirto.id/ sampah-rumah-tangga-bikin-kali-bekasi-tambahtercemar-c213.

19. Said N.I.. 2017. Waste Water Treatment Technology. Erlangga, Jakarta.

20. Setiawan A., Situmorang C. 2017. Different Tests of Waste Water Treatment Results of Exhaust Washing Cars and Motorbikes through a Physics Process Using Silica Sand and Activated Carbon Media. Jurnal Universitas Satya Negara Indonesia, 10(1), 11-17.

21. Yuliani R.L., Elly P., Yuni P. 201. Effect of waste laundry detergent industry against mortality and physiology index of nile tilapia (Oreochromis niloticus). Proc. Seminar Nasional XII Pendidikan Biologi FKIP UNS. 822-828. 